\title{
Histological Study of Common House Gecko (Hemidactylus frenatus) Regenerated Tail
}

\author{
Rakhmiyati ${ }^{1}$, Muhammad Jafar Luthfi ${ }^{2}$ \\ ${ }^{1}$ Postgraduate Program, Universitas Sebelas Maret \\ Jalan Ir. Sutami 36 A, Surakarta, 57126, Tel. +62271-646994, Fax. +62271-646655, Indonesia \\ ${ }^{2}$ Biology Department, Faculty of Science and Technology, UIN Sunan Kalijaga, \\ Jl. Marsda Adisucipto No 1 Yogyakarta 55281, Indonesia. Tel. +62-274-540971, Fax. +62-274-519739
}

Author correspondency:

miarakhmiy@gmail.com ${ }^{1}$

\begin{abstract}
Common house gecko (Hemidactylus frenatus) belongs to suborder Lacertilia that has capacity to shed its tail (autotomy) as a self-defense mechanism. After autotomy, tail regeneration occurs. Axiale skeleton of an original tail is composed of bony vertebrae, whereas the the regenerate one is comprised of cartilaginous tube. The purpose of this study was to determine the histological difference between axial skeleton of the original tail and the regenerate one of the common house gecko. Twenty four individuals consist of twelve common house gecko with original tail and twelve with regenerate tail were used. Microanatomical observations were carried on histological slide of original and regenerated tail stained with Hematoxylin-Eosin and Mallory Acid Fuchsin. The results showed that the original tail comprised of bony vertebrae whereas regenerated tail supported by cartilaginous tube.
\end{abstract}

Keywords: Common house gecko (Hemidactylus frenatus); autotomy; tail histology; cartilaginous tube of regenerated tail.

\section{INTRODUCTION}

Common house gecko belongs to the family Lacertidae that has the ability to autotomized its tail as defense mechanism. Caudal autotomy is the ability of an animal to shed off the tail to escape from predator (Lutfi, 2002; Soesilo, 1992). After autotomy, regeneration occurs (Kimball, 1983; Soesilo, 1992). The regeneration processes consist of three stages, namely the wound healing stage, blastema formation, differentiation and tail growth (Soesilo, 1992).

The original tail of Lacertid is composed of vertebrae caudales, the spinal cord located within the vertebral canal, perivertebral fat tissue, muscle layers, blood vessels, nerve, skin and scales (White, 1925 in Soesilo, 1999).

The regenerated tail differs from the original one. According to Soesilo (1999), the tail differs mainly in the structure of the vertebrae caudales and spinal cord. Instead of vertebrae, regenerated tail is supported by elongated cartilaginous tube, whereas the spinal chord is replaced by ependymal cells, glia cells and nerve fibers without nerve cell body (Soesilo, 1999).

The muscles of a regenerated tail also have a difference with the original tail muscle. Lacertid muscles arranged segmentally, consisted of 8 longitudinal bundles and each is limited by a septum composed by connective tissue. Seosilo (1999), stated that tail regeneration can occur when there is ependymal layer on the remaining spinal cord.

This study aimed to desribe histology of axial skeleton and muscle of regenerated tail of common house gecko (Hemidactylus frenatus).

\section{MATERIALS AND METHODS}

Twenty four common house geckos (body length ranges from 6.5 to $7.5 \mathrm{~cm}$, with intact tail) were used in this study.

Histological slides were made using paraffin method. Histological observation were done using light microscopy on histological slides stained with Hematoxylin-Eosin (HE) and Mallory Acid Fuchsin.

\section{RESULTS AND DISCUSSION}

From observation of original and regenerated tail of common house gecko it was found that there are difference in histological structure. 


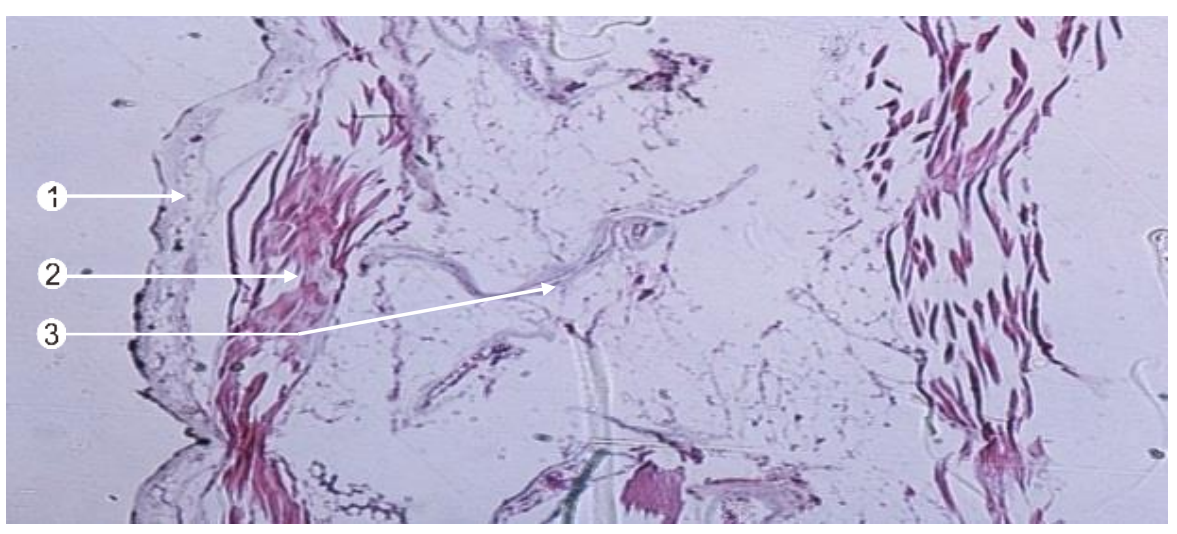

Figure 1. Longitudinal section of original tail (magnification 4x10). Hematoxylin eosin (HE). 1. Skin; 2. Muscles; 3. Autotomy septum.

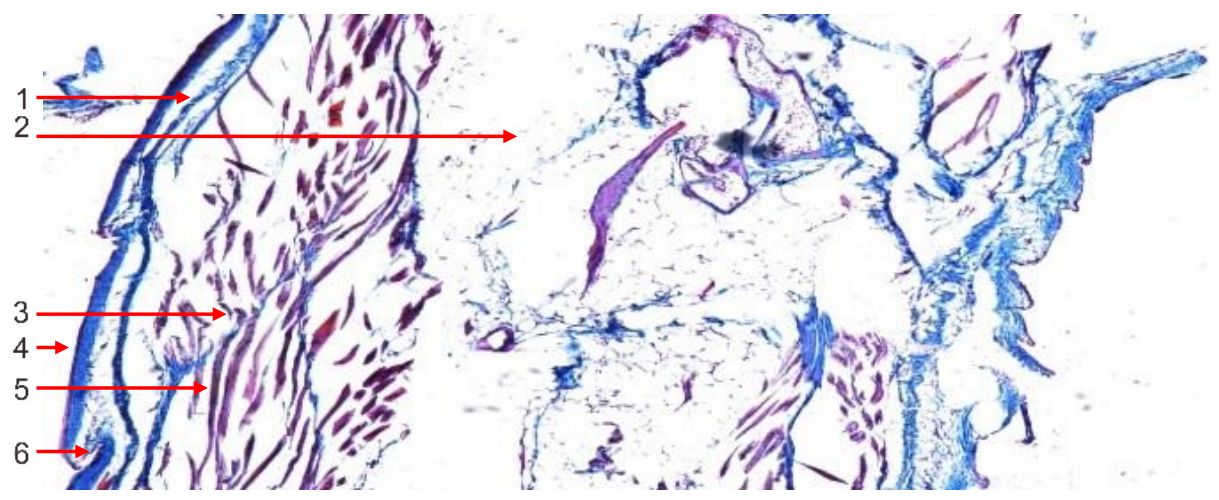

Figure 2. Longitudinal section of original (magnification 4x10). Mallory acid fuchsin. 1. Epidermis; 2. Perivertebral fat tissue; 3. Muscle segment; 4. Scales; 5. Muscles; 6 . Scale joint.

Autotomy plane is lied transversal (Figure 1). Autotomy plane serve to facilitate tail sheding for minimalized excessive blooding. Muscles pink colored due to Eosin staining. The skin on the tail of common house gecko is thin. In the original tail, skin has scales and joints of the scales with thin epidermis (Figure 2). Muscles are segmental. The vertebral fracture is seen in Figure 1.

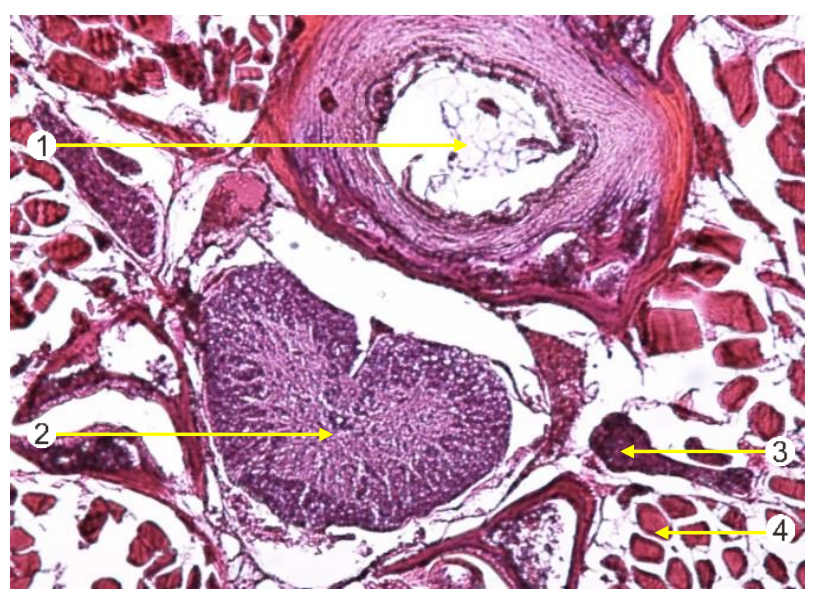

Figure 3. Cross section of original tail (10x10 magnification). Hematoxylin eosin (HE). 1. Centrum vertebrae; 2. Spinal cord; 3. Transverse process; 4 . Muscles.

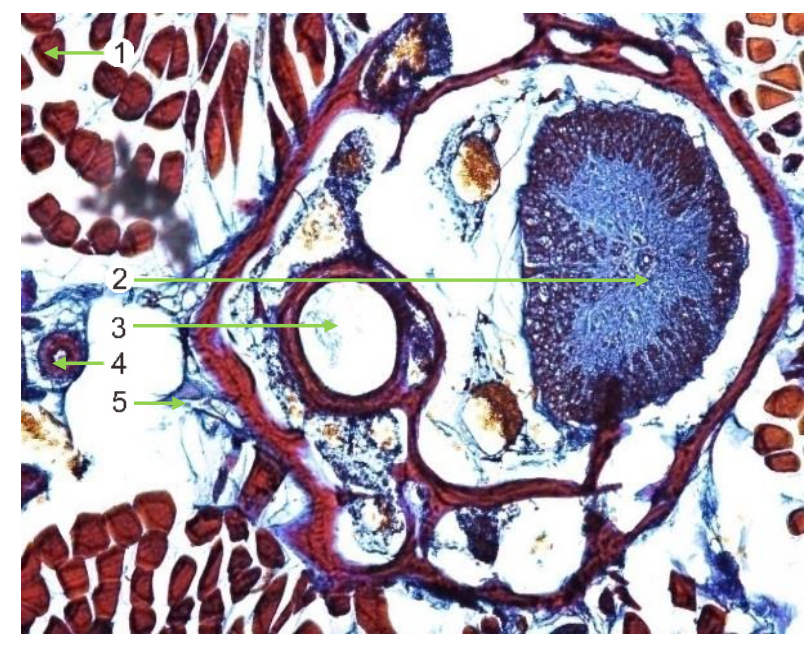

Figure 4. Cross section of original tail (10x10 magnification). Mallory acid fuchsin.1. Muscles; 2. Spinal chord; 3. Centrum vertebrae; 4. Caudal artery; 5 . Perivertebral fat tissue.

The muscle in the original tail is divided into 8 bundles and between bundles separated by septum (Figure 3). The transverses process is located at both side of vertebra. The original tail has a caudal artery. Centrum vertebrae are lied between the caudal artery and the spinal cord (Figure 4). The regenerated tail has a cartilaginous tube as a substitute for bony vertebrae and 
also has ependymocyti (Figure 5). The regenerated tail does not have a tranverse process like the original one. The figure shows that the cartilaginous tube has chondrocytes.

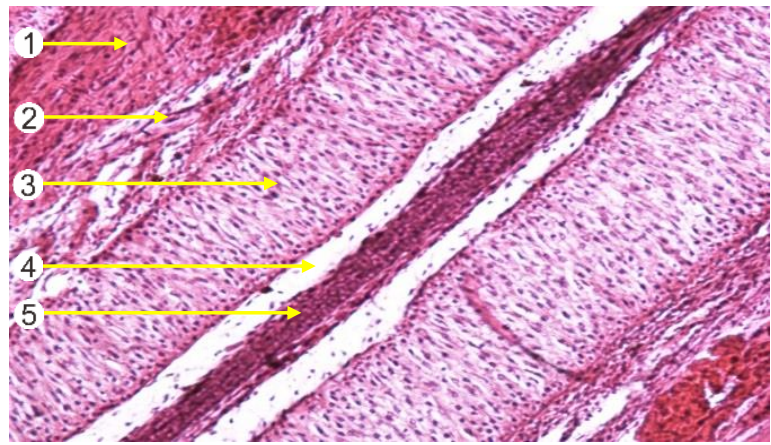

Figure 5. Longitudinal section of regenerated tail (20x10 magnification). Hematoxylin eosin (HE). 1. Muscles; 2. Perivertebral fat tissue; 3. Cartilaginous tube; 4. Meninx; 5. Ependymal cell.

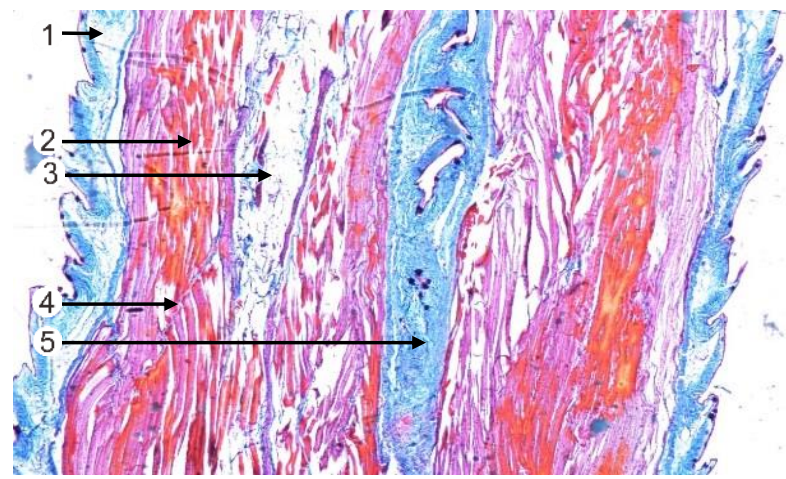

Figure 6. Cross section of lizard tail that has undergone autotomy $(4 \times 10$ magnification). Coloring: Mallory acid fuchsin. 1. Skin; 2. Muscles; 3. Perivertebral fat tissue; 4. Muscle segment; 5. Cartilago pipe.

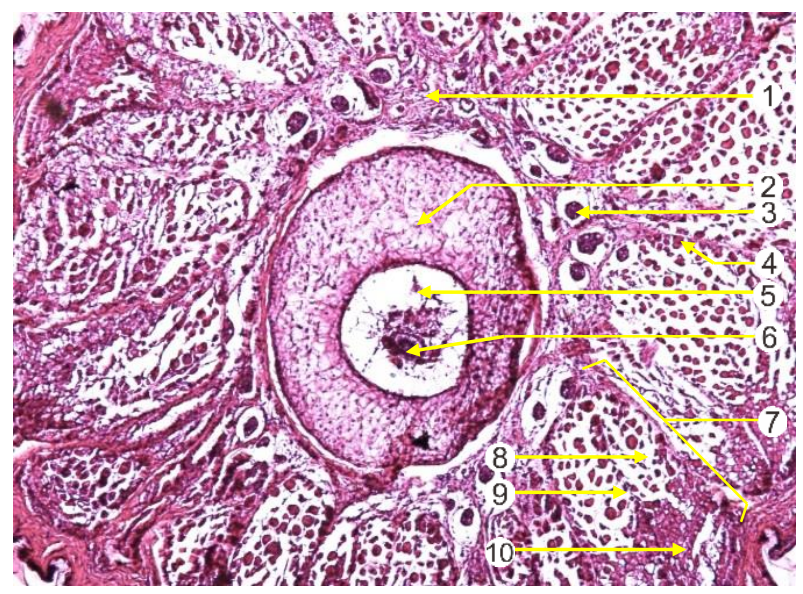

Figure 7. Cross section regenerated tail (10x10 magnification). Hematoxylin eosin (HE). 1. Perivertebral fat tissue; 2. Cartilaginous tube; 3. Nerves; 4. Septum; 5. Meninx; 6. Ependymocyti; 7. Muscles; 8. Myotomes; 9. Myoseptum; 10. Myotube.

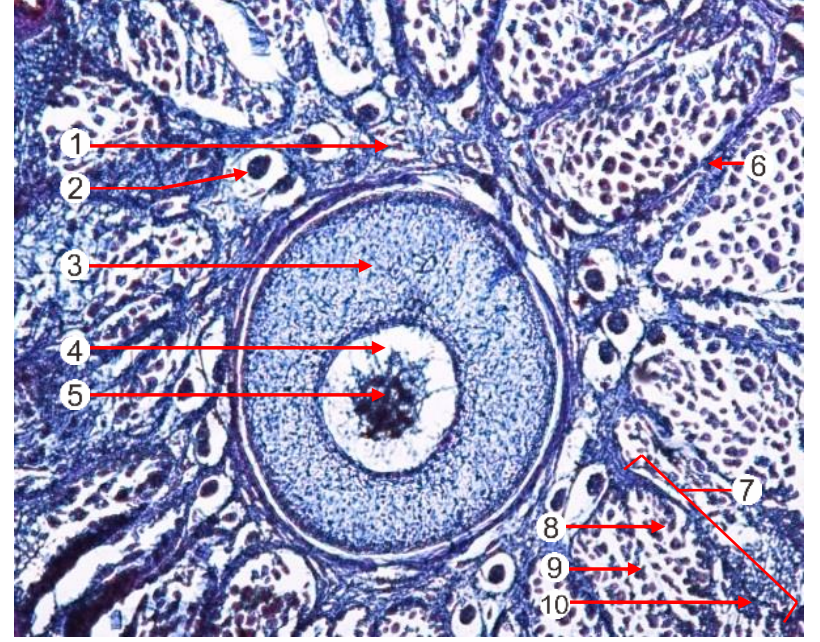

Figure 8. Cross section of regenerated tail (10x10 magnification). Mallory acid fuchsin. 1. Perivertebral fat tissue; 2. Nerves; 3. Cartilago pipe; 4 Meninx; 5. Ependymocyti; 6. Septum; 7. Muscles; 8. Myotomes; 9. Myoseptum; 10. Myotube.

The cartilaginous tube is surrounded by perivertebral fat tissue in which there are nerve cells (Figure 7). Figure 8 shows that perivertebral fat tissue surrounds the cartilaginous tube and in the fatty tissue there are nerve cells. There are ependymocyti in regenerated tail which play a role in cartilage formation.

\section{Observation of Cross and Longitudinal Sections on the Original Tail of the Common House Gecko (Hemidactylus frenatus)}

Observation of cross and longitudinal sections on the original tail of the common house gecko (Hemidactylus frenatus) stained with Mallory Acid Fuchsin and hematoxylin-eosin showed autotomy plane and transverse process on vertebrae caudales.

Autotomy plane is located along the tail from the base of the tail to the tip of the tail. The autotomy pane lies transversely and divides the vertebra and fat tissue into two parts: the anterior and posterior.

Vertebrae caudales of the original tail is surrounded by muscles. The muscle on the tail is a striated muscle. According to Irianto (2005), striated muscle is a muscle attached to the skeleton that can be moved. This muscle contracts quickly and strongly. In addition, striated muscles are also very sensitive to stimuli. The muscle of the regenerated tail is composed of multiple myotubes that merge into a myotomes. Myotomes are separated by myoseptum. The muscles of a regenerated tail are divided into 16 bundles. According to research conducted by Rachman \& Hadi (2008), the posterior part of original tail muscle of a lizard (Mabouya multifasciata Kuhl) has its origo on the chevron bone, spina neuralis, and transverse process, whereas the anterior part of the muscle inserted in the septum. Muscle of original tail is divided into 8 bundles. 


\section{Observation of Cross and Longitudinal Sections on Common House Gecko Regenerated Tail (Hemidactylus frenatus).}

The observation revealed that the regenerated tail is not supported by the bony vertebrae but cartilage or segmental cartilage (Figures 5, 6, 7, and 8). Inside the cartilaginous tube there is a layer of ependyma that is located parallel to the cartilage tube. According to Soesilo (1999), ependymal layer is very important in the process of tail regeneration and in the formation of cartilaginous tube.

Rachman \& Luthfi (2004) stated that calcification in cartilaginous tube of regenerated tail of lizard (Mabouya multifasciata) starting at 12 weeks of regeneration. This calcification process starts from the inner side and the outer side of the cartilaginous tube.

Cartilaginous tube of regenerated tail does not have an autotomy plane so the ability of autotomy in the regenerated tail is lower. Autotomy capability on the original tail is higher because it has autotomy plane.

\section{CONCLUSION}

Based on the results of the study, we drew conclusion as follows:

1. The original tail is composed of bony vertebrae, while the regenerated tail is composed by cartilaginous tube.

2. The regenerated muscle tail is divided into 16 bundles, while the original tail muscle is divided into 8 bundles.

\section{REFERENCES}

Alibardi, L. 1994. Muscle Differentiation and Morphogenesis in the Regenerating Tail of Lizards. Journal of Anatomy. 186: 143-151

Andayani, M.M.L. 2007. Mikroanatomi Ekor Kadal (Mabouya multifasciata Kuhl) Fase Penyembuhan Luka Setelah Autotomi dan Irradiasi Sinar Gamma. Thesis Universitas Gadjah Mada (Unpublished).

Anonim. 1985. Biology of the Reptilia (vol.15). New York: A Wiley-interscience publication.

Bateman, P.W \& Fleming, P. A. 2009. To Cut a Long Tail Short: A reviewof Lizard Caudal Autotomy Studies Carried Out Over the Last 20 Years. Journal of Zoology. London: The Zoological Society.

Bevelander, G \& Ramaley, J. A. 1988. Dasar-dasar Histologi. Translated by Wisnu Gunarso. Erlangga, Jakarta.

Beresford, W.A. 1983. Lecture Notes on Histology. Black well scientific publications, Oxford.

Carneiro, J \& Junqueira, L.C. 1992. Histologi Dasar (Basic Histology). Translated by Adji Dharma. Penerbit Buku Kedokteran EGC, Jakarta.

El- Karim, A. A. 1994. Regeneration from different levels along the tail of the geckonid lizard, Bunopus tuberculatus. Zoology. 1 (14): 82-89. Qatar: University of Qatar.
Finerty, J.C and Cowdry, E.V. 1962. A Text Book of Histology (Functional Significance of Cells and Intercellular Substances). Lea and Febiger, Philadelphia.

Gardner, Gray, dan O'Rahilly. 1995 . Anatomi (Kajian Ranah Tubuh Manusia). Translated by Z.S Bustami. Penerbit Universitas Indonesia, Jakarta.

Geneser, F. 1994. Buku Teks Histologi. Binarupa Aksara, Jakarta.

Hadi, S \& Rachman, A. 2008. Struktur Makro dan Mikroanatomi Otot Ekor pada Ekor dan Regenerat Ekor Kadal (Mabouya multifasciata Kuhl). Berkala Ilmiah Biologi. 6 (2): 81-86. Yogyakarta: Universitas Gadjah Mada.

Irianto, K. 2005. Struktur dan Fungsi Tubuh Manusia untuk Paramedis. Bandung: CV. Yrama Widya.

Kardong, K. V. 2006. Vertebrates: Comparative Anatomy, Function, Evolution. Washington State University: Mc Graw Hill Higher Education.

Kimball, J. W. 1983. Biologi. Fifth Edition. Jakarta: Erlangga.

Luthfi, M. J. 2002. Kalsifikasi Skeleton Aksial dan Kemampuan Autotomi Regenerat Ekor Kadal (Mabouya multifasciata $K u h l)$. Tesis. Universitas Gadjah Mada (Unpublished).

Luthfi, M. J, Soesilo, N.P, \& Sagi, M. 2003. Kalsifikasi Skeleton Aksial pada Regenerat Ekor Kadal (Mabouya multifasciata Kuhl). Jurnal Berkala Ilmiah Biologi, 3 (1): 1-8. Yogyakarta: Universitas Gadjah Mada.

Leeson, C.R, Leeson, T.S, and Paparo, A. A. 1996. Buku Ajar Histologi. Translated by Yan Tambayong dkk. Penerbit Buku Kedokteran EGC, Jakarta.

Maria, B. 1998. Struktur Vertebrae Caudales pada 5 Species Anggota Sub Ordo Lacertilia. Skripsi. Universitas Gadjah Mada (Unpublished).

Nahdi, M. S. \& Solihah, J. 2007. Buku Ajar: Biologi Umum. UIN Sunan Kalijaga Yogyakarta.

Pratiwi, I.R. 2009. Struktur Organ Reproduksi dan Seksual Dimorfisme pada Hemidactylus frenatus Dumeril \& Bibron, 1836; Cosymbotus platyurus (Schneider, 1792); \& Gekko gecko Linnaeus, 1758. Thesis Universitas Gadjah Mada (Unpublished).

Pratt, C.W.M. 1946. The Plane of Fracture of the Caudal Vertebrae of Certain Lacertilians. Journal of Anatomy. 80: 184-188.

Russell, A.P., Bergmann, P.J. \& Barbadillo, L.J. 2001. Maximal Caudal Autotomy in Podarcis hispanica (Lacertidae): The Caudofemoralis Muscle is not Sundered. American Society of Ichthyologists and Herpetologists. 1: 154-163.

Rachman, A \& Luthfi,M.J. 2004. Studi Histokimia Kalsifikasi Skeleton Regenerat Ekor Cicak (Hemidactylus sp), Jurnal Berkala Ilmiah Biologi. 3 (4): 223-230. Yogyakarta: Universitas Gadjah Mada.

Suntoro, S. H. 1983. Metode Pewarnaan (Histologi dan Histokimia). Jakarta: Bhratara Karya Aksara.

Soesilo, N. P. 2002. Pengaruh Regenerat Ekor Kadal (Mabouya multifasciata Kuhl) Terhadap Angiogenesis. Biologi. 2 (14) 833-844. Yogyakarta: Universitas Gadjah Mada.

Soesilo, N. P. 1982. Regenerasi Ekor Kadal (Mabuya multifasciata Kuhl) Setelah Mengalami Autotomi. Thesis. Universitas Gadjah Mada (Unpublished).

Soesilo, N. P. 1992. Proses Regenerasi Ekor Kadal (Mabouya multifasciata Kuhl). Biologi. 1 (4): 169-175.

Soesilo, N.P. 1999. Peranan Lapisan Ependima dalam Regenerasi Ekor Kadal (Mabouya multifasciata Kuhl). Biologi. 2 (8): 419-450. 
Takahashi, H. 2009. Preferensi Pakan Cicak rumah (Hemidactylus frenatus, Gray 1825) dan Tokek (Gekko gecko, Linnaeus 1758) di Gamping, Sleman, Daerah Istimewa Yogyakarta. Thesis. Universitas Gadjah Mada (Unpublished).
Yatim, W. 1996. Biologi Modern: Histologi. Bandung: Tarsito.

Zug, G. R. 1993. Herpetology an Introductory Biology of Amphibian and Reptiles. Academic Press. London. 